\title{
Correlation between Students' Risk-Taking Behavior and Students' Listening Comprehension
}

\author{
Ade Safrinal $^{1}$; Desi Surlitasari Dewi ${ }^{2}$; Aulia Putri ${ }^{3}$ \\ English Department \\ University of Riau Kepulauan \\ adesafrinal@gmail.com¹, belldaisy46@gmail.com², auliaputri1983@yahoo.com ${ }^{3}$
}

\begin{abstract}
Teachers of second language, should be aware of who their students really are. It means that teachers must comprehend diversities among their students in term of many kinds of personality traits and their links with second language skills. This study is aimed to find out the correlation between students' risk taking behavior and their listening comprehension at fourth semester students of English Department Universitas Riau Kepulauan in the academic year of 2015/2016. The study is done with quantitative procedure by using students' risk taking and listening comprehension's score to obtain the correlation between both of the variables. The finding of the research is that $r_{\text {calculated }}$ ($0.065)$ is lower than $r_{\text {table }}(0.456)$. It means that null hypothesis is accepted and alternative hypothesis is rejected. The finding of the study concluded that there is no correlation between students' risk taking and students' listening comprehension. Teachers can use this result as starting point to find the correlation between those variables and other variables in order to help the students in achieving better result in second language learning.
\end{abstract}

Keywords: correlation study, risk taking and listening comprehension

\section{INTRODUCTION}

Listening comprehension is considered as the most difficult subject among four skills to be learnt for foreign language learner due to misunderstanding when they are listening to something or the differentiation of meaning when it is translated to their mother tongue. The students are familiar with listening activity to their first language but lack of experiences in listening to native speaker. They become shock when they have to listen to native speaker and understand contain of narration to answer the question given. A great number of students start to be uncomfortable when they have to learn listening subject. They faced some difficulties to understand the listening contains and finally get unsatisfied score on listening comprehension test. 
Many research have been conducted in the correlation of student's personality traits and their achievement in language learning including listening comprehension. One of the personality traits which become popular in term of language learning field is Risk-Taking Behavior. It refers to a habit of taking a risk in uncertain situation and willing to face failure. Risk-taking behavior seems to be a factor which might get involved in daily life of human being activities in different level of ages (kids, teenagers, and adolescent); different sex (men and women); different job position (doctor, teacher, artist, employee, including university students). Regarding university students, based on researcher's own experiences and observation, it turned out that when the students are engaging in a listening comprehension test, they sometimes have to take risk in answering a question which they are not sure whether it is the correct answer or not. They are playing in uncertainty area with two possibilities; answering correctly or vice versa. By refers to the background, the problem of the study is formulated as "Is there any correlation between student's risk-taking behavior and their listening comprehension at fourth semester students of English Department of Universitas Riau Kepulauan in academic year 2015/2016?"

Vandergrift in Rahimi\&Soleymani (2015:152) defines listening is an interactive process of recognition, perception, and understanding of the oral input. In other perspective of thinking Gary (2001:31)defines listening as an active process of constructing meaning of a narration, speech or conversation and that is done by applying knowledge to incoming sound received by ears. While according to Brown (2003:118), listening is the invisible process in understanding the meaning of oral signals being transferred to our ear and brain. Furthermore, Sung et.al (2015:451) proposes listening as a cognitive process and, in reality, its context is not visible to the listener. On the other perspective of thinking, Gary (2001:3) defines listening comprehension asa outcome of interaction between number of information sources, which involves acoustic input, different type of linguistic knowledge, details of the context, and general word knowledge and so forth, and listener use whatever knowledge they have or whatever information seems relevant to help them interpret what the speaker is saying. Furthermore, Gary (2001:3) explains that listening comprehension is a process where the various knowledge get involved and they are all capable of interacting and influencing each other. According to Sung et.al (2015:451), listening comprehension is a dynamic and invisible process where the information is processed in listeners' working memory. Furthermore, Sung et.al (2015:451) explains that listeners first receive stimuli and then begin perceiving the stimuli and retrieving the prior knowledge from schema by performing a process for managing 
the information which involves basic language knowledge, such as phonological awareness, vocabulary, and grammar, for understanding the spoken text.

According to Dunkel\& Lim (2006:viii), there are some purposes of listening skill as follows:

1. By listening, the listener is able to scan the information they received orally.

2. By listening, people will be able to determine where they have to focus their attention in term of speech.

3. While listening, people will be able to create sense about what they hear from others whether in speech or conversation and then make a written or spoken response to demonstrate that they have processed the information correctly.

4. By listening, the listener also will be able to understand, remember and evaluate information they hear.

According to Dunkel \& Richard in Brown (2003:122), listening comprehension become difficult due to some reason as follows:

1. Clustering. It refers to understanding the appropriate 'chunks' of language phrases and clauses.

2. Redundancy. It refers to recognizing the kinds of repetitions \& elaborations that spoken language often contain.

3. Reduced Forms. It refers to understanding the reduced forms that may not have been a part of English learner.

4. Performance Variables. It refers to being able to 'weed out' hesitations, false starts, pauses and correction in natural speech.

5. Colloquial Language. It refers to comprehending idioms, slang, reduced forms, shared cultural language.

6. Rate of Delivery. It refers to keeping up with the speed of delivery, processing automatically as the speaker continues.

7. Stress, Rhythm, and Intonation. It refers to correctly understanding prosodic elements of spoken language. 
Arnett in Gullone \& Moore (2000:232), describes risk-taking behavior as thrillseeking behavior as having recognized but deliberately minimized dangers, and reckless behaviors that carry strong connotationsof serious negative consequences, including serious personal injury or death,conviction by the legal system, or other events that may have a longtermimpact.It shows that risk-taking behavior involves human being risky decision but on the other hand still consider the bad impact might happen thereafter. Trimpop (1994:9) defines risk-taking as aware and un-aware behavior, outcome and consequence of uncertainty, benefits and losses, intrinsic and extrinsic rewards, individual and societal risks. The statement shows that risk-taking behavior involves human being feeling of making a decision in term of certainty and uncertainty, loss and benefit, worry and hope in many kinds of activities they do in daily basis. Beebe in Engin et.al (2010:2) defines risk-taking behavior as situation where an individual has to make a decision involving choice between alternatives of different desirability; the outcome of the choice is uncertain; and there is a possibility of failure. The point of the statement is that risk-taking behavior is a situation when someone has to make decision in case of uncertain result of the action.

When a student is engaged in a listening comprehension task, he might has some uncertainty answer in his mind of a question given. He is in between certain and uncertain situation yet he has to make a decision immediately. He might be worry of making a mistake by answering a question wrongly, on the other hand he is also thinking of benefit by answering it correctly. When a student is in that kind of situation, he may not able to be focus to the next question and at the end will affect their overall listening comprehension task result. It might be the reason of correlation between risk-taking and students' listening comprehension.

\section{METHODOLOGY}

The research form that was used in this research was quantitative form. Quantitative form is a research design that primarily uses post positivist paradigm in the development of science ( such as the idea of cause and effect, the reduction of the variables, hypotheses, and specific question, use the measurements and observations, as well as testing the theory), using strategies such as experimental studies and survey requires statistical data (Emzir, 2008:28). This research was a correlation research as one of quantitative research models. The correlation 
research describes a general approach to a research that focus on assessment toward correlated variation among variables which arise naturally (Emzir, 2008:37).

The study was conducted at Universtitas Riau KepulauanBatam started from April 2016 to June 2016. The population of this research was the fourth semester students of English Department of UNRIKA Batam in the academic year of 2015/2016 which consists of four classes and approximately 100 students. Then, researcher took class B as the sample of the research which contains of 19 students represented whole classes of fourth semester students by using cluster random sampling technique.

To get the data of students' risk taking, researcher used questionnaire items which were developed from some risk-taking indicators proposed by Trimpop (1994:239). They were : voluntary risk-taking, performance oriented, paratelic, intrinsic motivation, primary active control, problem are challenges, arousal seeking, strong nervous system, high emotional reactivity, high desire for control, high need for achievement, and hope for success. While to get the data of students' listening comprehension, researcher used Communicative StimulusResponse Task since this kind of listening comprehension test is appropriate with university students due to their level of knowledge which was taken from International English Language Test System (IELTS) as international standard. The validity and reliability of both instruments are tested before the instruments given to the students as sample of research. Only valid and reliable instruments are used to get research data.

\section{RESULT}

\section{Testing Instruments}

\section{Risk taking questionnaire}

\section{a. Validity of questionnaire}

Validity of questionnaire is tested by using Pearson Product Moment Formula as performed below:

$$
r_{\text {calculated }}=\frac{N\left(\sum x y\right)-\left(\sum x\right)\left(\sum y\right)}{\sqrt{\left\{N\left(\sum x^{2}\right)-\left(\sum x\right)^{2}\right\}\left\{N\left(\sum y^{2}\right)-\left(\sum y\right)^{2}\right.}}
$$

Where:

$\mathrm{N}$ = number of respondent

$\mathrm{X}=$ variable score (respondent answer)

$\mathrm{Y}=$ total score of variable for respondent number $\left(\mathrm{n}^{\text {th }}\right)$ 
The result is that from 25 items of questionnaire, 24 of them were valid and 1 of them was invalid.

\section{b. Reliability of questionnaire}

24 valid items then are tested by using Alpha Cronbach Formula to obtain their reliability as performed below:

$$
r_{11}=\left\{\frac{k}{k-1}\right\}\left\{1-\frac{\sum o b^{2}}{a_{t}^{2}}\right\}
$$

Where:

$$
\begin{array}{lll}
r_{11} & & =\text { reliability of questionnaire } \\
& \mathrm{k} & =\text { number of item } \\
\sum_{a^{2} o^{2} b} & =\text { Number of item variance } \\
a^{2}{ }^{2} & =\text { total variance }
\end{array}
$$

The reliability coefficient of questionnaire was 0.96 means that questionnaire was reliable.

\section{Listening comprehension test}

\section{a. Validity of listening comprehension test}

Validity of listening test is tested by using Pearson Product Moment Formula as performed below:

$$
r_{\text {calculated }}=\frac{N\left(\sum x y\right)-\left(\sum x\right)\left(\sum y\right)}{\sqrt{\left\{N\left(\sum x^{2}\right)-\left(\sum x\right)^{2}\right\}\left\{N\left(\sum y^{2}\right)-\left(\sum y\right)^{2}\right.}}
$$

Where:

$$
\begin{aligned}
& N=\text { number of respondent } \\
& X=\text { variable score }(\text { respondent answer) } \\
& Y=\text { total score of variable for respondent number }\left(n^{\text {th }}\right)
\end{aligned}
$$

From 40 items of listening test for try out, researcher found 27 items were valid and 13 items were invalid.

\section{b. Reliability of listening comprehension test}

Researcher use only 25 valid items for its practicality and have represented all indicators of listening comprehension test. The reliability of listening test was tested by using Kuder Richardson 20 (KR-20) formula to obtain their reliability. 
Researcher found the coefficient reliability of listening test $\left(\mathrm{r}_{11}\right)$ is 0.92 which is bigger than 0.7 means that the test items were reliable.

\section{Data Analysis}

Only valid and reliable instruments being distributed to the research sample to get the data. There are two kinds of data in this research. First, students listening comprehension score which is obtained by using listening test and the second is students' risk taking score which is obtained by using risk taking questionnaire items. The result of the data analysis is that the coefficient correlation between $\mathrm{X}$ variable and $\mathrm{Y}$ variable $\left(\mathrm{r}_{\text {calculated }}\right)$ is smaller than $\mathrm{r}_{\text {table }}(-0.065$ $<0.456)$ means that null hypothesis $(\mathrm{Ho})$ is accepted and alternative hypothesis $\left(\mathrm{H}_{1}\right)$ is rejected. Based on the hypothesis testing result, researcher found no correlation between risk taking and listening comprehension due to the value of $r_{\text {calculated }}$ which is smaller than $r_{\text {table. A risk avoider }}$ student might has high listening comprehension so either a risk taker student as performed by sample number 15 (risk avoider student) and sample number 17 (risk taker student) who got 68 in their listening comprehension test. On the other hand, both of risk taker and risk avoider students might have low listening comprehension as performed by sample number 9 (risk taker) and sample number 11 (risk avoider) who got 36 on their listening comprehension test. It might happen since whether a student is a risk taker or risk avoider does not affect their ability in understanding a narration or conversation which usually given while a listening comprehension test. Their ability in understanding main idea or details of a narration and how good they are in making inferences which are the listening test indicators have no correlation with how they treat the problem (as challenge or as threat), what motivation they have (extrinsic or intrinsic), and whether they need achievement or not which are the parts of risk taking indicators.

Whether a student is a risk avoider or a risk taker has no correlation with their achievement in listening comprehension test. Risk taking is not one of affective aspects which have correlation with listening comprehension. In listening comprehension test, students' knowledge of the topic given, their understanding of native speaker pronunciation and their focus while the test is carrying which involved on how they can answer the question correctly might have no correlation with their willingness to take a riskhence knowing students' level of risk taking is not necessary in term of their listening comprehension. 


\section{DISCUSSION}

Based on data analysis in the previous chapter, the finding of this research is that the coefficient correlation between $\mathrm{X}$ variable and $\mathrm{Y}$ variable $\left(\mathrm{r}_{\text {calculated }}\right)$ is smaller than $\mathrm{r}_{\text {table }}(-0.065$ $<0.456)$ means that null hypothesis $(\mathrm{Ho})$ is accepted and alternative hypothesis $\left(\mathrm{H}_{1}\right)$ is rejected. From the finding itself, it can be concluded that there is no correlation between students' risk taking and students' listening comprehension. It means that risk taker students do not always have high listening comprehension or vice versa. The result of the study states that there is no correlation between students' risk taking and students' listening comprehension. Teachers can use this research result to help them in understanding the diversities among their students in term of students' risk taking trend while trying to find out other affective aspects which might has correlation with students' listening comprehension.

\section{REFERENCES}

Brown Steven. (2006). Teaching listening. New York: Cambridge University Press.

BurguguAssiye, Han Turgay, Engin Ali Osman \& Kaya Dursun. (2010).Who are our students? Investigating learners' risk taking ability. Retrieved from: https://www.researchgate.net/publication/277056140_Who_are_Our_Students_Investigati ng_Learners'_Risk_Taking_Ability_and_Achievement_on_Second_Language_Acquisitio n.

Dunkel A. Patricia \& Lim Phyllis. (2006). Intermediate listening comprehension. Boston: Thomson Heinle.

Emzir.(2008). Metodologi penelitian pendidikan. Jakarta: Raja Grafindo Persada.

Pei-Ju Sung, Su-Wei Lin \& Pi-Hsia Hung. (2015). Factors affecting Item Difficulty in English Listening Comprehension Tests. Universal Journal of Educational Research 3 (7): 451-459, 2015. doi: 10.13189/ujer.2015.030704.

Rahimi \& Soleymani.(2015). The impact of mobile learning on listening anxiety and listening comprehension. English Language Teaching; Vol. 8, No. 10; 2015. doi:10.5539/elt.v8n10p152. 